\title{
Growth of Brachiaria brizantha planted at different densities and seasons in Santa Fé system with a culture of soybean
}

\author{
Eduardo A L Erasmo1, Rogério C Gonçalves', Jhansley F Da Mata1, Vinícius A Oliveira², Luíz P F Benício3* \\ ${ }^{1}$ School of Agronomy, University of Tocantins, Gurupi, Brazil, '2School of Agronomy, University of Goiás - Goiânia, Brazil, 'Department of Soil, \\ University of Viçosa - Viçosa, Brazil
}

\section{A B S TR A C T}

\begin{abstract}
This study aims to evaluate the density and planting period of the grass Brachiaria brizantha in consortium with the soybean. The study was conducted under field conditions at the experimental station of University of Tocantins. The experimental design used was a randomized block design, in factorial scheme of $(2 \times 5)+4$, with four repetitions, including both sowing of Brachiaria brizantha (20 and 30 days after the emergence - DAE, of soybeans), five Brachiaria seeding densities $\left(0,3,6\right.$, 9, and $12 \mathrm{~kg}$ of seed ha $\left.{ }^{-1}\right)$ and Brachiaria grown individually in the four densities tested, constituting itself as witness reference. To assess the growth of the Brachiaria, the plants contained in an area of $(0.33 \times 0.40 \mathrm{~m})$ to 140 DAP of soy were collected in each plot, determining the number of tillers per plant; height and dry weight of shoots; leaf dry mass and dry mass stalk. Data were submitted to regression analysis. The cultivation of Brachiaria intercropped with soybean provoked a decrease in all parameters evaluated. The increase in the density of sowing promoted a reduction in the tillering and an increase in dry matter production and height of the plant.
\end{abstract}

Keywords: Crop-Livestock integration; Competition; Deployment pasture; Piatã grass

\section{INTRODUCTION}

Latin America has millions of hectares under pasture in the most varied conditions of soil and climate; these areas are responsible almost for the entire feed of bovine cattle, where the predominant species are forage grasses (Alves et al., 2012). According to Dias-Filho (2011), Brazil has about 180 million hectares of pastures, and it is estimated that between 50 and $70 \%$ of these areas are degraded or have some degree of degradation.

Currently, there is a great pressure on the opening of new areas for food production and for those production systems to be sustainable. Therefore, it becomes necessary to adopt these techniques to recover degraded areas reincorporating them into the productive system, so that they remain productive. Among the alternatives available, one of the most promising is the integration of livestock with annual crops.
In crop-livestock integration (CLI) annual crops are sown into pastures for beef or dairy cattle. It has agronomic, social and environmental benefits. This technique has been researched in the Projeto de Integração Lavoura-Pecuária ("Draft Crop-Livestock Integration") (PILP) developed by Brazilian Agricultural Research (Embrapa), with the establishment of pastures by Santa Fé System, which is to produce annual crops intercropped with forage plants, avoiding the reduction in yield of annual crops and providing a high quality forage production for season (Cobucci et al., 2001).

Among the advantages of using the CLI, the ones that stand out are: the refurbishment or renovation of degraded pastures, the improvement in physical and biological conditions of the soil, the grain and forage production in the same area, the reduction in the use of external inputs, and the cost reduction in both agricultural and livestock activity (Alvarenga and Noce, 2005).

\footnotetext{
${ }^{*}$ Corresponding author:

Luíz P F Benício, Department of Soil, University of Viçosa - Viçosa, Brazil. E-mail: luizpaulo.figueredo@gmail.com

Received: 12 April 2016; Revised: 8 August 2017; Accepted: 15 August 2017; Published Online: 20 August 2017
} 
The intercropping system among cultures is used in many parts of the world and, in general, has been more productive than monocultures (Silva et al., 2004). The intercropping system is defined as a cultivation system in which there is simultaneous growth of two or more species of biological enable interaction between them (Vandermeer, 1989). However, certain combinations of crops result in increased competition among crops for water, light and nutrients, leading to reduced productivity, making some crops inappropriate for intercropping (Fukai and Trenbath, 1993).

The main factors that determine competitiveness in the intercropping between forage and culture are related, among others, to the population density, to the sowing time and to the culture to be used.

An efficient way to reduce the problems caused by competitiveness is the adoption of cultural practices such as spatial arrangement of plants (Oliveira et al., 1996), which can be done by sowing the density of forage or row spacing of the annual crop. According to Alvarenga and Noce (2005) competitiveness problems can be circumvented by applying sub-doses of herbicides, aiming to the reduction of forage growth, or by delayed planting of forage about 20 to 40 days after sowing the crop. However, both of these practices should be well managed in order to succeed.

What has been found in the studies of CLI is the performance of annual crops, often leaving the forage outside evidence. Thus, the present study aimed to evaluate the development and production of Brachiaria brizantha $\mathrm{cv}$. BRS Piatã (Piatã grass) planted at different times and densities intercropped with soybean, implanted in Santa Fé system.

\section{MATERIALS AND METHODS}

The study was conducted under field conditions at the experimental station of University of Tocantins, at the Gurupi Campus, located in the southwestern region of the state of Tocantins, localized in coordinates $11^{\circ} 43^{\prime} 45^{\prime \prime} \mathrm{S}$ e $49^{\circ} 04^{\prime} 07^{\prime \prime} \mathrm{W}$, with an altitude of 280 meters. According to Köppen (1948), the regional climate is humid B1WA 'a' with moderate water deficit. The average annual temperature is of $29.5{ }^{\circ} \mathrm{C}$, and the average annual precipitation is $1.804 \mathrm{~mm}$, with wet summer, dry winter and high water deficit between the months of May and September (Fig. 1).

The experimental soil area was classified as a tipic oxisol with the following chemical characteristics: $\mathrm{pH} \mathrm{CaCl}_{2}$ 4.7; Ca: $2.1 \mathrm{cmol}_{\mathrm{c}} \mathrm{dm}^{-3} ; \mathrm{Mg}: 0.4 \mathrm{cmol} \mathrm{dm}_{\mathrm{c}}^{-3} ; \mathrm{Al}: 0.2 \mathrm{cmol}_{\mathrm{c}} \mathrm{dm}^{-3}$; $\mathrm{Al}+\mathrm{H}: 2.7 \mathrm{cmol}_{\mathrm{c}} \mathrm{dm}^{-3} ; \mathrm{P}(\mathrm{Mel}): 7.1 \mathrm{mg} \mathrm{dm}^{-3} ; \mathrm{K}: 51.6 \mathrm{mg}$ $\mathrm{dm}^{-3}$; CTC: $2.8 \mathrm{cmol}_{\mathrm{c}} \mathrm{dm}^{-3}$; V: 49\%; M.O: $1.9 \%$.

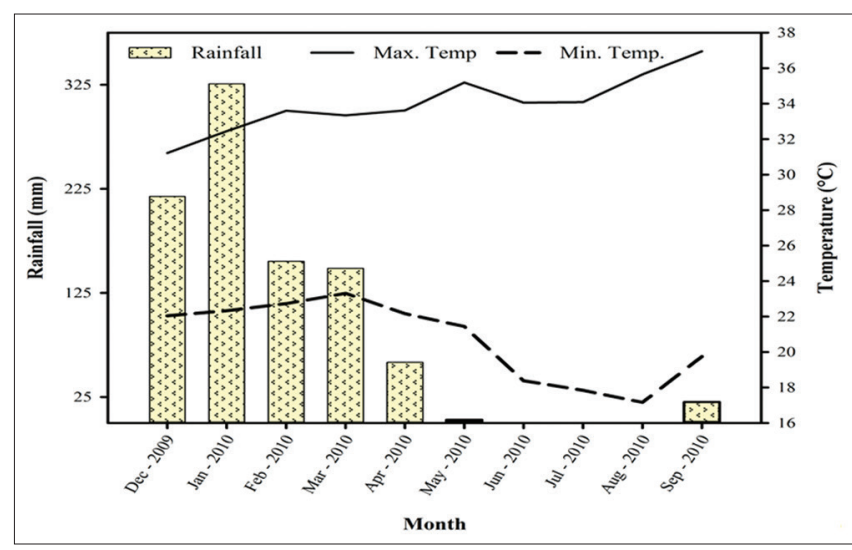

Fig 1. Minimum and maximum temperature, and average rainfall during the crop cycle in the agricultural year 2009/2010. Gurupi - TO. Source: INMET/UFT.

The experimental design chosen was a randomized block design, in the factorial scheme of $(2 \times 5)+4$, with four replications, corresponding to two sowing periods of Piatã grass (20 and 30 days after emergence - DAE, of soybean RR soybean cultivar RR M-8527), five of forage seeding rates $\left(0,3,6,9\right.$ and $12 \mathrm{~kg}$ seed $\left.\mathrm{ha}^{-1}\right)$ and forage grown separately in the four densities tested, becoming a control of reference.

The soybean planting was held on December $30^{\text {th }}, 2009$ by means of a Semeato SHM 11/13 fertilizer and seed spreader (model of direct planting), with row spacing of $0.40 \mathrm{~m}$ density of 30 plants per $\mathrm{m}^{2}(12$ plants per meter), corresponding to a population of 300.000 plants ha ${ }^{-1}$.

Prior to the sowing, the seeds were inoculated with Bradyrbizobium japonicum. On the occasion of seeding, a fertilizer was applied at $600 \mathrm{~kg} \mathrm{ha}^{-1}$ of $0-20-20$, as recommended by the analysis of soil, following the recommendations of Ribeiro et al., (1999). The soy culture emerged on January $3^{\text {rd }}, 2010$.

The sowing of Piatã grass was performed at 20 and 30 DAE of soybean corresponding to V2 and V5 stages, respectively. The furrow sowing was $0.2 \mathrm{~m}$ away from the line of soybeans, and with a $0.03 \mathrm{~m}$ depth.

Each experimental unit consisted of an area of $10 \mathrm{~m}^{2}$ $(5 \mathrm{~m} \times 2 \mathrm{~m})$, corresponding to five ranks, with the area that displayed sowing utility being of $4.8 \mathrm{~m}^{2}$, comprising the three central rows (disregarding $0.4 \mathrm{~m}$ at its end).

As phytosanitary control over the development of culture, $300 \mathrm{~g}$ i.a. $\mathrm{ha}^{-1}$ of the insecticide Tamaron BR (methamidophos $600 \mathrm{~g} \mathrm{~L}^{-1}$ ) were applied. The weed root control was carried out with the application of $2 \mathrm{~L} \mathrm{ha}^{-1}$ of glyphosate (glyphosate $480 \mathrm{~g} \mathrm{~L}^{-1}$ ) before the sowing of Brachiaria. 
To assess the growth of Brachiaria, the plants contained in an area of $0.133 \mathrm{~m}^{2}(0.333 \mathrm{~m} \times 0.40 \mathrm{~m})$ to 140 DAP of soy were collected in each plot, determining the number of tillers per plant, the height of plants using a graduated scale, taking the measurement from the ground level to the apex. After measuring, the plants were cut to $20 \mathrm{~cm}$, the stems were separated from the leaves, and both were packed in paper bags and placed in a forced-ventilation greenhouse at $60^{\circ} \mathrm{C}$ until was constant weight was reached. Following this stage, the height and the dry weight of shoots, the leaf dry mass and the stalk dry mass were determined.

The data were subjected to an analysis of variance by $\mathrm{F}$ test, and the averages of the evaluated characteristics were subjected to a regression analysis. The models adjustments were made based on their significance and the coefficient of determination $\left(\mathrm{R}^{2}\right)$, based on the recommendations of Alvarez V. and Alvarez (2003). The results were subjected to a regression analysis using the statistical software Microcal Origin 6.1.

\section{RESULTS AND DISCUSSION}

The results related to the height of the Piatã grass are in Fig. 2. We are able to see that the height of the plants of the Piatã grass responded linearly to the increased seeding density ( $p<0.05)$, regardless of the sowing date and of being intercropped or grown alone. Regardless of sowing periods, cultivating grass intercropped with soybean resulted in lower altitudes than when grown alone. When seeded at $20 \mathrm{DAE}$, the Piatã grass decreased by $49 \%$ in height when compared to its isolated cultivation. As for when the seeding occurred at $30 \mathrm{DAE}$, this reduction was even higher, reaching $54 \%$.

The highest height of the plants offered by increased seeding rate may be explained by the competition for light. High densities stimulate apical dominance of hormonal nature of plants making these plants have increased the height (Sangoi et al., 2002). The authors also report that phytochrome has great importance in the hormonal role of apical dominance. Several species have shown that the extreme red $(\mathrm{Re})$ and red $(\mathrm{R})$ radiation bands may change the growth and distribution of photoassimilates through phytochromes (Almeida, 1998). Thus, the high density of plants provides an increase in the Re/R ratio due to the large increase of reflection of $(\mathrm{Re})$ by plants (Kasperbauer and Karlen, 1994). Such increase in the $\mathrm{Re} / \mathrm{R}$ ratio suppresses the tiller development and stimulates the apical dominance (Almeida et al., 2002). Therefore, the intense densification increases the Re/R ratio, triggering physiological events that lead to the plant prioritizing the allocation of photoassimilates to the main

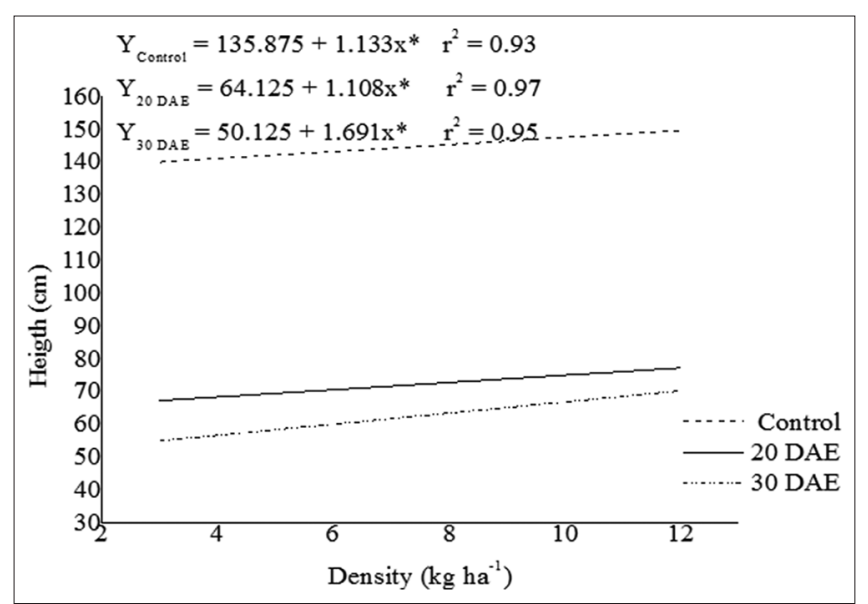

Fig 2. Height (cm) of Brachiaria brizantha plant. BRS Piatã, grown alone or intercropped with soybean, due to different densities. *Significant $(p<0.05)$.

stem; it results in the suppression of the development of lateral branches. Also according to Salisburry and Ross (1992), the close proximity to plants caused by the compression of planting reduces oxidation of auxin, promoting cell elongation.

The fact of the intercropping with soy having lower growth than when cultivated in isolation can also be explained by the competition, but, in this case, an interspecific competition, not only for light. The different plant species react to each type of competition differently, but despite the important role in the organization of individuals in a given habitat, the competition, either intraspecific or interspecific, is responsible for reducing the development and productivity of many crops (Castro and Garcia, 1996).

The fact that the sowing of Piatã grass has occurred after the soybean emergence has provided such conditions that there was shading to the forage, resulting in delayed development. Jakelaitis et al. (2010), during the evaluation of the effects of weed interference on the pasture implementation of Brachiaria brizantha, found a critical period of weed competition on the grassy of 9 to 26 days after emergence. When the Piatã Grass was sown at 20 and 30 days after soy emergence, the soybean was in the V3 and V5 stages, respectively. Thus, when the plants of Piatã grass were sown, a stressful condition in relation to light availability was observed, especially at $30 \mathrm{DAE}$, once having $\mathrm{C} 4$ metabolism of $\mathrm{CO}_{2}$ fixation requires more light.

According to Duarte et al. (1995), competition relations between annual crops and pastures vary with the morphology and initial growth rate of the species used. In this study, the forage had a lower competitive ability than the soybean, reproducing the obtained results by (Portes et al. 2000; Silva et al. 2005), wherein the Brachiaria brizantha 
suffered from the effect of competition when grown in the intercropping.

In Fig. 3, we find the results for the number of tillers in Piatã grass due to increased seeding rate. For this parameter, the grass displayed a linearly negative response $(p<0.05)$ to both $20 \mathrm{DAE}$ and control, and $(\mathrm{p}<0.01)$ for $30 \mathrm{DAE}$ regarding its $\beta$ and $r^{2}$ coefficients. As previously mentioned, the increased density stimulates the apical dominance of the plants, reducing their tillering and promoting their vertical growth. When grown in isolation, the density increase caused reductions in the number of tillers per plant in the order of $23 \%$, comparing with each other, the densities of 3 and $12 \mathrm{~kg} \mathrm{ha}^{-1}$. However, when grown intercropped with soybean, the decreases were of $38 \%$ and $43 \%$, corresponding the sowing times of 20 and 30 DAE, respectively.

This reduction of tillering when the species is grown in intercropping may also be explained by interspecific competition. The interplant competition is the biggest limiter to the increase of the population of stems in grasses (Milhollon and Legendre, 1995; Silva et al., 2007). The shading provided by soybean resulted in a lower amount of light radiation in the lower strata of the pasture, a place where most of tillering occur, triggering reactions that reduced tillering, as reported by (Langer, 1963). The quality of light in this region is also altered. With the reduction of red light, there is a delay for buds to develop into tillers (Deregibus et al., 1983). In this way, the number of axillary buds is reduced (Skinner and Nelson, 1992).

As for the leaf dry weight, the results can be seen in Fig. 4. The responses of the dry mass of leaves due to the increase of planting density were linear, having no significance for plants sown at 20 DAE, with significance $(p<0.05)$ for plants sown at $30 \mathrm{DAE}$ and $(p<0.01)$ for the control regarding the $\beta$ coefficients. Again, it can be seen that the Piatã grass, when grown in isolation, gave better results than when cultured in the intercropping. The sowing date also showed a significant effect on the mass production of leaves, being the 20 DAE planting being higher than 30 DAE.

Analyzing the decrease in leaf dry mass of the Brachiaria developed in harmony with soybeans, when compared with the isolated culture, we find a reduction of 27 and $16 \%$, planted at $20 \mathrm{DAE}$, for sowing densities of 3 and $12 \mathrm{~kg} \mathrm{ha}^{-1}$, respectively. When the seeding of Brachiaria was performed at $30 \mathrm{DAE}$, these reductions were higher, corresponding to 49 and $55 \%$ for sowing densities of 3 and $12 \mathrm{~kg} \mathrm{ha}^{-1}$, respectively.

In Fig. 5, we see the results of the production of dry mass of stems. It is observed that the intercropping between

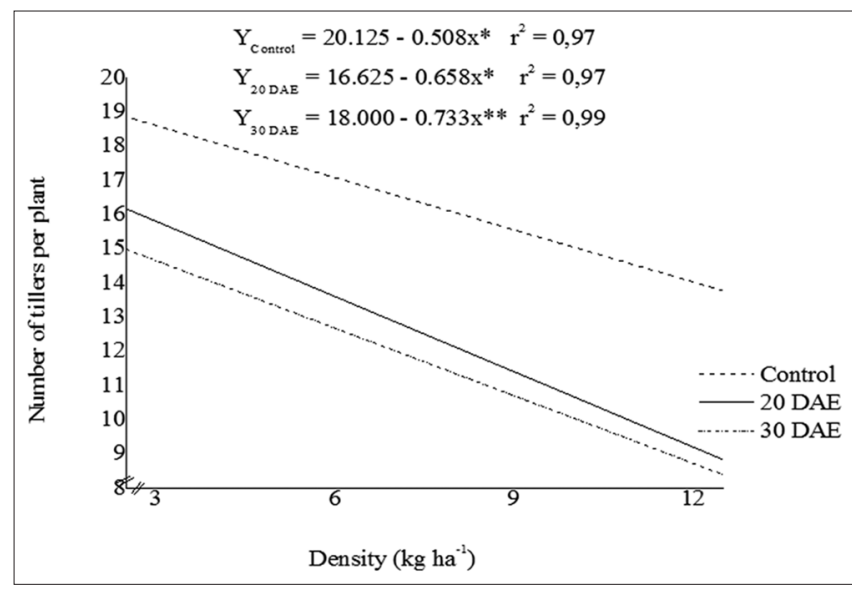

Fig 3. Number of tiller per plant in Brachiaria brizantha plant. BRS Piatã, grown alone or intercropped with soybean, due to different densities. * Significant $(p<0.05) .{ }^{* *}$ Significant $(p<0.01)$.

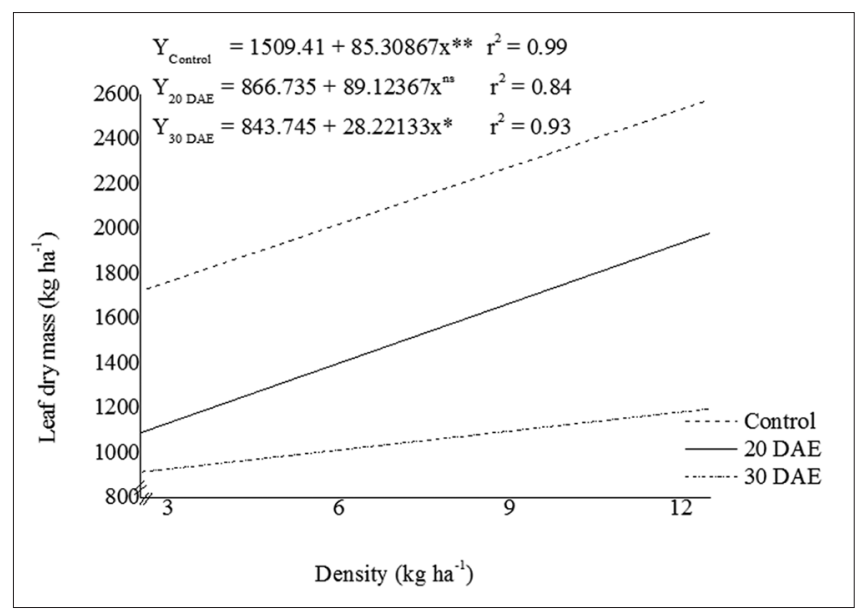

Fig 4. Leaf dry mass (kg ha ${ }^{-1}$ ) of Brachiaria brizantha plant. BRS Piatã, grown alone or intercropped with soybean, due to different densities. ${ }^{n s}$ Not significant. ${ }^{*}$ Significant $(p<0.05) .{ }^{* *}$ Significant $(p<0.01) .{ }^{n s}$ Not significant.

Piatã grass and soybeans, regardless of sowing date, obtained inferior results to those obtained when grown in isolation. The decrease of dry mass stalk of Piatã grass intercropped with soybean planted at 20 DAE, when compared with the isolated cultivation, was of 73.32 and $63 \%$ for sowing densities of 3 and $12 \mathrm{~kg} \mathrm{ha}^{-1}$, respectively. When sowing grass was performed at 30 DAE, these reductions were greater, corresponding to 85 and $86 \%$ for sowing densities of 3 and $12 \mathrm{~kg} \mathrm{ha}^{-1}$, respectively.

Regarding the increase of planting density, the production of dry mass of Piatã grass stems presented positive linear correlation $(p<0.05)$ for control and seeded at 30 DAE, but was not significant nor to the grass seeded at $20 \mathrm{DAE}$, nor to $\beta$ coefficients.

The results of the total production of dry weight of shoots are shown in Fig. 6. Increasing the seeding rate resulted in 
a linear correlation $(\mathrm{p}<0.01)$ for grass intercropped with soybean seeded at $30 \mathrm{DAE}$, and $(\mathrm{p}<0.05)$ for the control. As it occurred for dry mass of leaves and dry weight of stems when grown in isolation, the Piatã grass got bigger productions; when grown in a intercropping disregarding of the sowing date, there was a significant reduction in the production of dry weight of shoots. Analyzing the decrease in dry mass of the aerial part of the Brachiaria developed in harmony with soybeans, when compared with the isolated culture, we find a reduction of 53 and $46 \%$, planted at 20 DAE, for sowing densities of 3 and $12 \mathrm{~kg} \mathrm{ha}^{-1}$, respectively. When the sowing of Piatã grass was performed at $30 \mathrm{DAE}$, these reductions were higher, corresponding to 69 and $75 \%$ for sowing densities of 3 and $12 \mathrm{~kg} \mathrm{ha}^{-1}$, respectively.

According to Frank and Hofman (1994); Martuscello et al. (2009); Benício et al. (2013), the production of matter from one grazing area is proportional to the number of tillers of the grass in the area; however, this effect was not detected in this work, since the higher seeding rates resulted in smaller

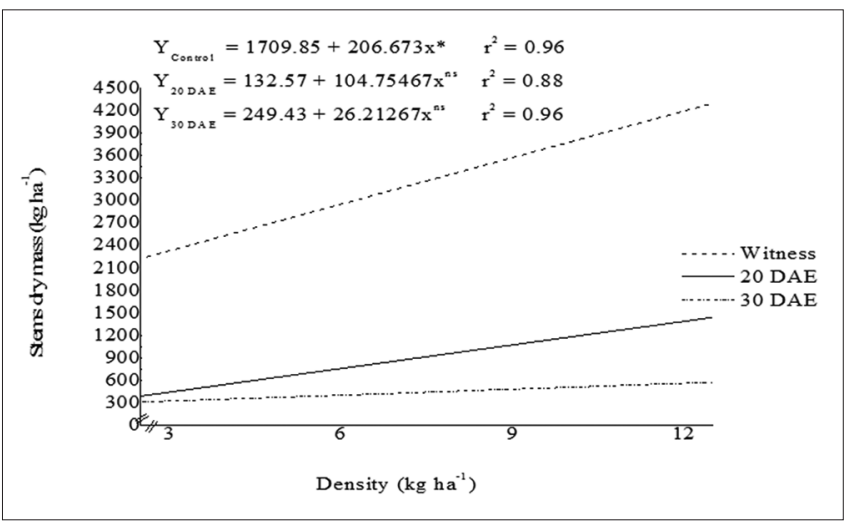

Fig 5. Stems dry mass $\left(\mathrm{kg} \mathrm{ha}^{-1}\right)$ of Brachiaria brizantha plant. BRS Piatã, grown alone or intercropped with soybean, due to different densities. ${ }^{*}$ Significant $(p<0.05)$. ${ }^{n s}$ Not significant.

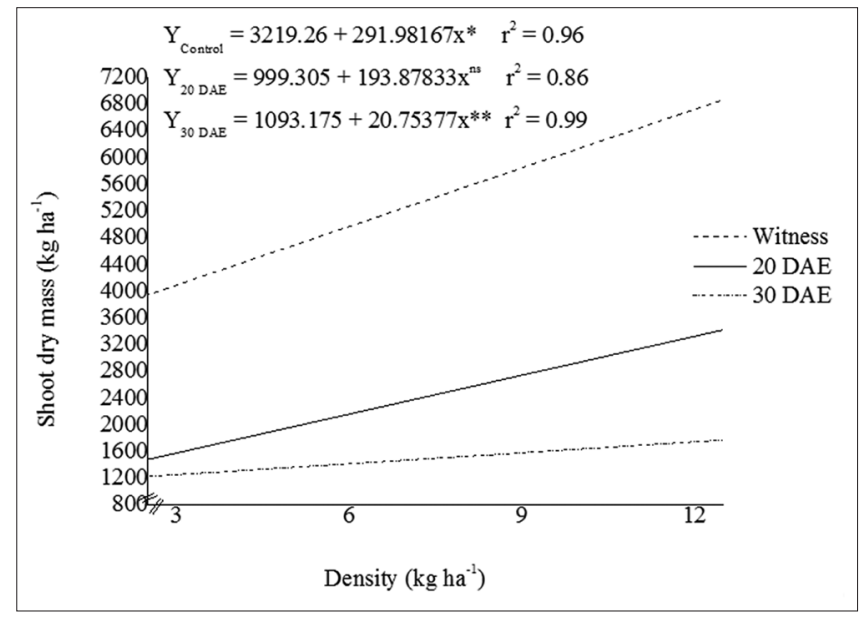

Fig 6. Shoot dry mass (kg ha $\left.{ }^{-1}\right)$ of Brachiaria brizantha plant. BRS Piatã, grown alone or intercropped with soybean, due to different densities. ${ }^{\text {ns }}$ Not significant. ${ }^{*}$ Significant $(p<0.05)$. ${ }^{* *}$ Significant $(p<0.01)$. numbers of tillers and higher dry matter production. This result is explained by the compensation effect reported by Sbrissia and Da Silva (2001), when the plant presents a low number of tillers, it compensates it with the production of heavier tillers. The reverse also occurs: when the plant has a higher number of tillers, they tend to be lighter.

Regarding the intercropping treatments having lower yields of leaf, stem and total dry mass, this response can again be attributed to the competition between plants. The soybeans, being in a more advanced stage, are able to have greater competitive ability for water, light or nutrient. It is made evident when we see the results of forage seeded at $30 \mathrm{DAE}$, where lower yields were obtained. These results can be enhanced by data from Walker et al., (1988) the authors emphasize that plants that grow faster compete more effectively for light. Castro and Garcia (1996) report that the effects of competition on the development and production of plants vary widely, because these results depend on the stage at which the plants are; however, competition for light is the kind of competition that interferes the most with development and production due to interference exerted over the aerial parts of the plant.

Portes et al. (2000) reported that, in the pasture/crop intercropping, when the forage emerges relatively delayed in comparison to the culture, is is weakened by shading and displays low production and slow growth, especially for being a plant with a $\mathrm{C}_{4}$ metabolism. This trait makes them very demanding when under light.

Productivity of forage when intercropped can be attributed to low, because it does not exceed $3500 \mathrm{~kg} \mathrm{ha}^{-1}$ of dry weight for sowings taken at $20 \mathrm{DAE}$, and $2000 \mathrm{~kg} \mathrm{ha}^{-1}$ for sowings at 30 DAE. Nevertheless, at first, the greatest focus is the production of soybeans. Grasses in the Bracbiaria gender has great capacity for regrowth, providing a quick recovery; with the removal of the annual crop, its production can quickly be equated with the production achieved when grown in isolation, as reported by Portes et al. (2000). In the present study, although the mass of the material after removal of soy was not quantified, it is possible to verify the total closure of the area with little presence of weeds, showing that the Santa Fé System can be an alternative for simultaneous production of grain and forage.

\section{CONCLUSIONS}

The intercropping between forage and soy promoted competitive effect, reducing the productivity of forage when compared to cultivation of forage in isolation. 
The late sowing of forage provided a good initial development for soybeans, delaying the initial development of forage due to competition for light. The productivity of forage was reduced when seeding was performed at a 30 DAE treatment with lower productivity.

Higher seeding rates were more promising regarding their productivity in the establishment of pastures by Santa Fé System.

The Santa Fé System implemented with late sowing forage was shown to be efficient, for it allowed satisfactory grain production. Subsequently, the grassland formed by the total closure of the area was also obtained.

\section{REFERENCES}

Almeida, M. L. 1998. Modification of Tillering of Wheat and Oats by Light Quality. Doctor Scientiae Thesis, University of Rio Grande do Sul, Porto Alegre.

Almeida, M. L., L. Sangoi, P. S. Trentin and J. Galio. 2002. Wheat cultivars tiller emission and dry mass accumulation react differently to light quality. Ciênc. Rural. 32: 377-383.

Alvarenga, R. C. and M. A. Noce. 2005. Crop-Livestock Integration. EMBRAPA-Corn and Sorghum. EMBRAPA Milho e Sorgo, Sete Lagoas.

Alvarez, V. V. H. and. G. A. M. Alvarez. 2003. Presentation of regression equations and their interpretations. Bull. Braz. Soc. Soil Sci. 28: 28-32.

Alves, S. J., R. M. L. Alves and J. A. Soler. 2012. Evaluation of herbicides for establishing star grass by seedlings with root on degraded pastures of Brachiaria. Ambiência Rev. Setor Ciênc. Agrárias Ambientais. 8: 895-900.

Benício, L. P. F., S. O. Lima and V. M. Santos. 2013. Evaluation of different levels of phosphate rock tailings in the development of Piatã grass in the absence and presence of lime. Magistra. 25: 221-234.

Castro, C. R. T. and R. Garcia. 1996. Competition among plants for the light recourse. Ciênc. Rural. 26: 167-174.

Ribeiro, A. C., P. T. G. Guimarães and V. H. Álvares. 1999. Recommendations for the use of Lime and Fertilizers in Minas Gerais. $5^{\text {th }}$ ed. University of Viçosa, Viçosa.

Cobucci, T., J. Kluthcouski and H. Aidar. 2001. Santa Fé System: Forage production in off season. In: Workshop International Program of Integrated Crop Livestock for Sustainable Development of the Tropical South American Savanas. Santo Antônio de Goiás, Brazil. pp. 125-135.

Deregibus, V. A., R. A. Sanchez and J. J. Casal. 1983. Effects of light quality on tiller production in Lolium spp. Plant Phisiol. 27: $900-912$.

Dias-Filho, M. B. 2011. Degradation of Pastures: Processes, Causes and Recovery Strategies. $4^{\text {th }}$ ed. MBDF, Belém.

Duarte, J. M., H. E. Pérez, D. A. Pezo, J. Arze, F. Romero and P. J. Argel. 1995. Production of maize (Zea mays L.), soybean (Glycine max L.) and cowpea (Vigna unguiculata (L.) Walp) planted in association with grasses in the humid tropics. Pasturas Trop. 17: 12-19.
Frank, A. B. and L. Hofman. 1994. Light quality and stem numbers in cool-season forage grasses. Crop Sci. 34: 468-473.

Fukai, S. and B. R. Trenbath. 1993. Process determining intercrop productivity and yields of component crops. Field Crops Res. 34: 247-271.

Jakelaitis, A., J. O. Gil, L. S. Simões, K. V. Souza and J. Ludtke. 2010. Effects of weed interference in the implementation of Brachiaria brizantha pasture. Rev. Caatinga. 23: 8-14.

Kasperbauer, M. J. and D. L. Karlen. 1994. Plant spacing and reflected far-red light effects on phytochrome-regulated photosynthate allocation in corn seedlings. Crop Sci. 34: 1564-1569.

Köppen, W. 1948. Climatology: A Study of the Climates of the Earth. Fondo de Cultura Econômica, México.

Langer, R. H. M. 1963. Tillering in herbage grass. A review. Herbage Abstr. 33: 141-148.

Martuscello, J. A., L. Jank, M. M. Gontijo Neto, V. A. Laura and D. N. F. V. Cunha. 2009. Genus Brachiaria grass yields under different shade levels. Rev. Bras. Zootec. 38: 1183-1190.

Milhollon, R. W. and B. L. Legendre. 1995. Influence of ethephonon plant population and yield of sugarcane (Saccharum spp. hybrids). Plant Growth Regul. Soc. Am. Q. 23: 17-30.

Oliveira, I. P., J. Kluthcouski, L. P. Yokoyama, L. G. Dutra, T. A. Portes, A. E. Silva, B. S. Pinheiro and E. M. Ferreira. 1996. Barreirão system: Restoration/renovation of degraded pastures intercropped with annual crops. Embrapa-CNPAF, Goiânia.

Portes, T. A., S. I. C. Carvalho, I. P. Oliveira and J. Kluthcouski. 2000. Growth analysis of a cultivar brachiaria in monocrop and intercropped with cereals. Pesqui. Agropecu. Bras. 35: 1349-1358.

Salisburry, F. B. and C. W. Ross. 1992. Plant Physiology. $4^{\text {th }}$ ed. Belmont: Wadsworth Publishing.

Sangoi, L., M. L. Almeida, P. R. F. Silva and G. Argenta. 2002. Morpho-physiological bases for greater tolerance of modern maize hybrids to high plant densities. Bragantia. 61: 101-110.

Sbrissia, A. F. and S. C. Da Silva. 2001. The ecosystem of pastures and livestock production. Annual meeting of Brazilian society of animal science. Piracicaba. 38: 733-754.

Silva, A. C., L. R. Ferreira, A. A. Silva, A. F. Belo and C. S. Sediyama. 2005. Morphologic characters of soybean and Brachiaria intercropped under reduced rates of fluazifop-p-butil. Ciênc. Rural. 35: 277-283.

Silva, A. C., L. R. Ferreira, A. A. Silva, T. W. B. Paiva and C. S. Sediyama. 2004. Effects of reduced rates of fluazifop-pbutyl on soybean intercropped with Brachiaria brizantha. Planta Daninha. 22: 429-435.

Silva, M. A., G. S. C. Gava, M. M. Caputo, R. P. Pincelli, E. M. Jerônimo and J. C. S. Cruz. 2007. Use of plant growth regulators as improvers of tillering and of productivity in sugarcane ratoon. Bragantia. 66: 545-552.

Skinner, R. H. and C. J. Nelson. 1992. Estimations of potential tiller production and site usage during tallfescue canopy development. Annal. Bot. 70: 493-499.

Vandermeer, J. 1989. The Ecology of Intercrop. Cambridge University Press, Cambridge.

Walker, G. K., R. E. Blackshaw and J. Dekker. 1988. Leaf área and competition for ligth between plant species using direct sunligth tranmission. Weed Technol. 2: 159-165. 